\title{
Ecology of Fish Communities in Coral Habitats Along the Coast of Pakistan: Potential Threats and Conservation Strategies
}

\author{
Amjad Ali ${ }^{1 *}$, Pirzada Jamal Ahmad Siddiqui', Naveed Ahmad ${ }^{2}$, Shabir Ali Amir ${ }^{3}$, \\ Rafaqat Masroor $^{3}$, Seema Shafique ${ }^{1}$ and Zaib-un-Nisa Burhan ${ }^{1}$ \\ ${ }^{1}$ Center of Excellence in Marine Biology, University of Karachi, Karachi 75270 \\ ${ }^{2}$ Aquatic Diagnostic Laboratories, Bahria University, Karachi Campus, Karachi \\ ${ }^{3}$ Zoological Sciences Division, Pakistan Museum of Natural History, Garden Avenue, \\ Shakarparian, Islamabad
}

\begin{abstract}
A B S T R A C T
Reef ecosystem is an important source of recreation and fish diversity. Present study aimed to record the distribution and diversity of fishes from different coral habitats along the coast of Pakistan. Additionally, potential threats and conservation strategies were also discussed. SCUBA diving was conducted at 10 different dive sites along the coastline. Relative abundance of the fishes was determined using visual techniques. Sea water physiochemical parameters were determined. A total of 58 fish species in 33 genera and 24 families were recorded at 10 different dive sites. High diversity occurred at Churna Island following Mubarak Village and Astola Island. Majority of the recorded fishes were planktivorous. Compare to Churna and Mubarak Village, physico-chemical parameters at Astola Island were found in limits as preferred by fish and coral communities for their proper growth. Fish accumulation appeared to be link with coral cover, diversity and growth forms. Low diversity at Astola Island was mainly due to habitat destruction caused by increasing anthropogenic activities (coral mining, careless SCUBA and skin diving, entangling of corals by fishing nets and mechanical damage by deployment of lobster pots). Conservation efforts should focus on the establishment of effective marine protected areas, involvement of different stakeholder (well reputed research institutes, universities, dive centers, tour operators, local community), making tourism laws and their implementation, rehabilitation of microhabitats for fish communities through the involvement of local community and creating awareness in general public on the significance (ecological, commercial) of these natural resources via print and electronic media for a sustainable ecotourism. Further, to better understand the effects, regular monitoring monitoring and scientific research (environmental, biological parameters) is recommended.
\end{abstract}

\section{INTRODUCTION}

$\mathrm{R}$ eef ecosystem is important source of recreation and fish diversity. World third of marine fish species exist in reef environment (Maragos et al., 1996; Veron et al., 2009; Plaisance et al., 2011). Reef provides $25 \%$ of the total fish, consumed by humans. Several millions of people living in at least 99 countries (having coast line with reefs) depend on corals for their food requirements (Teh and Sumaila, 2013). Fishes play a diverse and central role in marine ecosystems. During recent decades, as a result of increasing sea surface temperature and anthropogenic activities (tourism effects, increase in nutrient and sediments load, release of toxic material etc.), reefs degradation has occurred globally. Changes in reef habitats

\footnotetext{
* Corresponding author: aalimbku@hotmail.com 0030-9923/2021/0004-1341 \$9.00/0

Copyright 2021 Zoological Society of Pakistan
}

have inserted remarkable effects on the abundance and distribution of reef associated fishes. Future changes can alter ecosystem functions and fish productivity (Pastorok and Bilyard, 1985; Naim, 1993; Maragos et al., 1996; Riegl, 2002; Chittaro, 2004; Loya, 2007; Hay and Rasher, 2010; Gladstone et al., 2013; Hernández-Delgado et al., 2014; Pratchett et al., 2014; Heron et al., 2016).

In future, major threats for reef fishes will be increasing sea surface temperature and atmospheric carbon dioxide concentration across the globe. These changes will affect food chain, population connectivity, recruitment dynamics and decrease in fish diversity. Many of the reef fishes are living close to thermal optimal condition and an adequate increase in temperature will reduce aerobic space, habitat destruction and effect on behavior and physiological performance of reef fishes (Munday et al., 2008, 2012; Nowicki et al., 2012). Moreover, it is evident that change in water temperature and carbon dioxide concentration due to climate change can alter fish fitness by altering their 
behavior, reduction in acclimation ability, response to environmental changes, reduction in hypoxia forbearance capacity of reef fish, reduction in respiratory performance and damage of chemosensory responses to predators (Nilsson et al., 2010; Ferrari et al., 2012; Nowicki et al., 2012; Couturier et al., 2013; Enzor et al., 2013). Beside climate change effects, sewage pollution is a major threat for reef associated communities. Increase in nutrient level will enhance the growth of algae and filter feeders in water column. This increase (algae and filter feeders) will decreases oxygen level and reduce coral cover (Pastorok and Bilyard, 1985; Szmant, 2002).

Many researchers conducted studies on the ecology of reef fishes on global (e.g. Reese, 1975; Thompson and Munro, 1978; Williams and Hatcher, 1983; Shulman, 1985; Pet-Soede et al., 2001; Graham et al., 2003; Marshall et al., 2003) and regional scale (e.g. Downing, 1985; Smith et al., 1987; Coles and Tarr, 1990; Krupp and Miiller, 1994; Fouda et al., 1998; Kemp, 1998; Rezai and Savari, 2004).

Locating on the northern part of the Arabian Sea, Pakistan covers a major portion of the Arabian Sea with a coast line of $1050 \mathrm{~km}$, distributed between Sindh $(250 \mathrm{~km})$ and Balochistan provinces $(800 \mathrm{~km})$. The major portion of the coast (Balochistan coast) is still tectonically active. The coast is under the influence of reversal monsoons. Upsloping brings up nutrient that support macroalgal growth (Haq, 1988; Shameel and Tanaka, 1992; Ali and Memon, 1995; Wiggert et al., 2000; Ali et al., 2017). Corals along the coast are mainly confined to offshore waters (Churna and Astola Islands) while in coastal areas at some locations are mostly patchily distributed (Ali et al., 2014). Studies on reef associated fishes from the coastal waters of Pakistan are lacking though a considerable information are available on their taxonomy (i.e. Bianchi, 1985; Hoda, 1988; Amir et al., 2013, 2014, 2016). These studies were mainly based on samples collected either from fish harbors or even captured using different nets without knowledge of their ecology. The current study displays the outcomes of surveys undertaken in coral habitats along the coast of Pakistan and an overview of the features of the visited sites and fish communities. Additionally, potential threats to fish communities and conservation strategies were also discussed.

\section{MATERIALS AND METHODS}

\section{Study sites}

Study was conducted at 3 sites, 2 along the Sindh coast (Mubarak Village (MV) and Churna Island (CI)) and 1 along the Balochistan coast at Astola Island (AI) (Fig. 1). The locations were selected on the basis of coral cover. Mubarak Village is located at $24^{\circ} 51^{\prime} \mathrm{N}, 66^{\circ} 39^{\prime} \mathrm{E}$ and approximately $45 \mathrm{~km}$ towards west from Karachi. The substratum is rocky. It is a sport fishing site and people also come for snorkeling and diving. Churna is a small, Island off the coast of Karachi and is located at $24^{\mathrm{O}} 53 \mathrm{~N}$ and $66^{\mathrm{O}} 36 \mathrm{E}$, about $50 \mathrm{~km}$ west of Karachi. The substratum is rocky. The Island is well known fishing and recreational site. Recreational fishermen frequently visit the Island where there is enough sea life to attract anglers for big game fishing from all over Pakistan. Astola Island is comparatively larger than Churna Island, located at $25^{\circ} 07^{\prime} \mathrm{N}, 63^{\circ} 50^{\prime} \mathrm{E}$ and about $30 \mathrm{~km}$ south of the Balochistan coast. The Island has an area of about $4 \mathrm{~km}^{2}$, being $4 \mathrm{~km}$ long, $1 \mathrm{~km}$ wide and typically $60 \mathrm{~m}$ high. There are numerous sandy beaches on the northern side of the Island. These beaches are essential nesting sites for different species of turtles (green and leather back). Recently the Island is declared as a Marine Protected area (Dawn, 2017). The substratum at the Island is mostly rocky, composed of sandstone and calcareous sandstone (Shah, 2009). The Island is also considered as a hot coral spot in offshore waters along the coast (Ali et al., 2014).

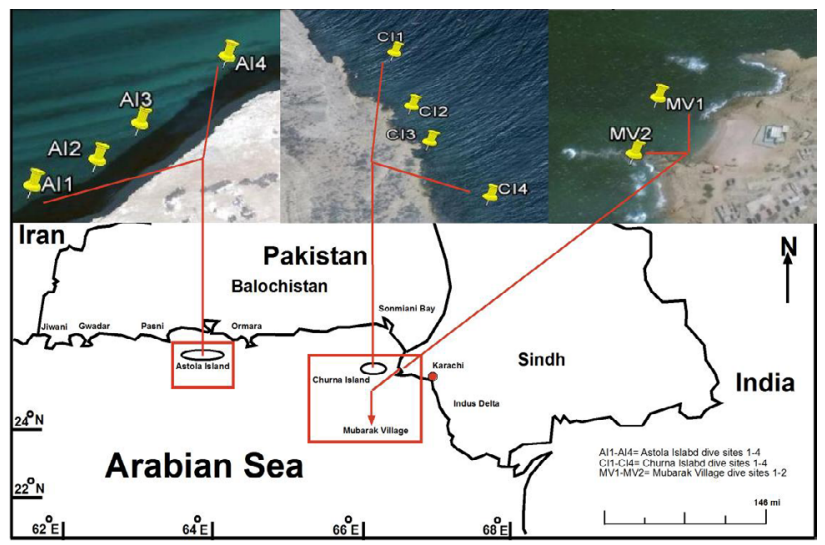

Fig. 1. Map of Pakistan coast. Insets showing study sites.

\section{Methods}

SCUBA diving was conducted at 10 dive sites, 6 along the Sindh coast (1 each at MV1, MV2 and 4 at CI) and 4 at northern sheltered site of Astola Island along the Balochistan coast (Fig. 1). Surveys along the Sindh coast were conducted between January to March 2014 while along the Balochistan coast, during February 2018. In situ observations, GPS coordinates and depth at each site was noted (Table I). Fish abundance at each site was determined visually using 1 to 6 mathematical scale (6 $($ dominant $)=$ up to300 individuals; 5 (abundant $)=$ up to 200 individuals; 4 (common) $=$ up to 50 individuals; 3 (frequent) $=$ up to 20 individuals; 2 (occasional) $=$ up to 10 individuals, $1($ rare $)=$ up to 5 individuals $)$. Considerable 
numbers of species were identified in situ while for others, relayed on underwater photographs, taken using a digital camera (Fine Pix F660EXR) in an underwater housing. Following Froese and Pauly (2018), fishes were further classified on the basis of their feeding level. Fishes were identified using available literature (Kuiter and Debelius, 2007; Bianchi, 1985; Carpenter et al., 1997).

\section{Seawater physico-chemical parameters}

Seawater physico-chemical parameters along the Sindh coast were not determined but relayed on previous study, conducted by Ali et al. (2017) while physical parameters (temperature, salinity, dissolved oxygen, $\mathrm{pH}$ ), inorganic nutrients (nitrate, nitrite, phosphate, ammonia) and organic content (chlorophyll a) along the Balochistan coast were determined in triplicate. Temperature $\left({ }^{\circ} \mathrm{C}\right)$ and dissolved oxygen $(\mathrm{mg} / \mathrm{L})$ were determined using Dissolved Oxygen/Temp. Waterproof Tester (EZDO 7031). Salinity was determined using refractometer (ATAGO 0161633 Japan) while $\mathrm{pH}$ was determined using $\mathrm{pH}$ meter (Hanna HI98107). Water samples for inorganic and organic contents were collected in lid covered plastic bottles, stored in ice box and brought to laboratory. Analyzes of the samples were performed following Strickland and Parsons (1972).

\section{Data analysis}

Cluster techniques were used to examine relations between sites based on root square transformation of data and Bray-Curtis similarity index (Bray and Curtis, 1957; Clarke and Warwick, 2001; Clarke, 1993). Frequency distribution of species at 10 diving sites was perceived using K. dominance curve (Lambshead et al., 1983). Multivariate analysis was piloted using PRIMER v.6 software package (Clarke and Gorely, 2006).

\section{RESULTS}

\section{Fish communities}

A total of 58 fish species in 33 genera and 24 families were recorded at 10 different dive sites. Among these, 51 were identified at species level whereas 5 up to genus level. Relative abundance and diversity of fishes at each site is shown in Table II. High fish diversity occurred at northern sheltered sites of CI following MV and AI. Fish habitat (coral) degradation was observed at AI and MV. Also, diseased corals were seen at Astola Island. Out of 58 species 7 (Chromis flavaxilla, Pseudochromis aldabraensis, Pseudochromis omanensis, Pseudochromis springeri, Scarus arabicus, scarus zufar, Scorpaenopsis barbatus) have a confined distribution, mostly limited to Arabian Sea and Red Sea region. Two species (Diplodus capensis, Abudefduf vaigiensis) were also reported from the Atlantic including western Indian Ocean, whereas 49 had a wide distribution range i.e. Indian Ocean, western Indian Ocean or western Pacific.

Based on feeding level, most of the recorded fishes were planktivorous (18 species) followed by invertivorous (16 species), carnivores (12 species), herbivorous (8 species), invertivorous and carnivorous (2) and omnivorous (2 species). A cluster analysis for fish communities at 10 dive sites showed that the northern sheltered sites of the Astola Island, Churna Island and MV1 (AI1 and AI4, AI2 and AI3, CI1 and CI3 and CI4 and MV1) formed well defined clusters at similarity levels of $80 \%, 75 \%, 67 \%$ and $57 \%$ whereas MV2 and CI2, formed separate clusters at similarity levels of $35 \%$ and $60 \%$ approximately (Fig. 2). The K dominance curve showed that species-frequency distribution is high at $\mathrm{CI}$ 2 trailed by CI 1, CI 4, CI 3, MV1, AI 2, AI3, MV 2, AI 4 and AI 1 (Fig. 3).

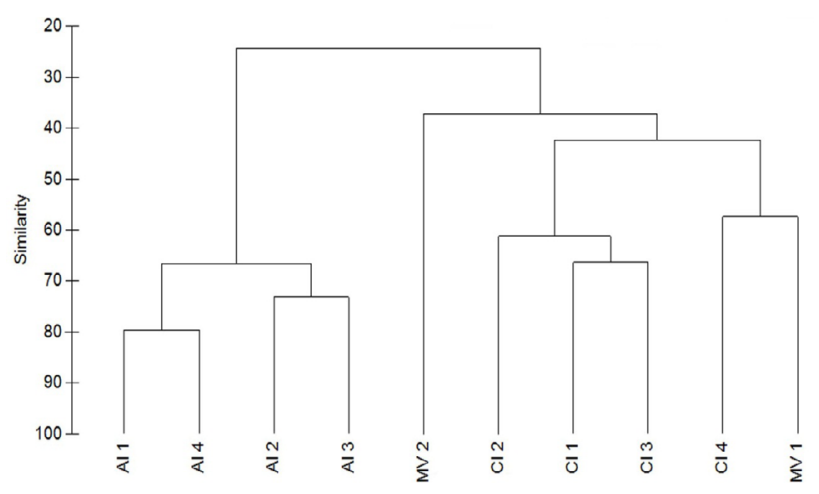

Fig. 2. Cluster analysis for fish communities using group average linkage techniques at 10 dive sites, based on root square transformation and Bray-Curtis similarity index. Symbols are as, MV1-2, Mubarak Village dive sites 1-2; CI1-4, Churna Island dive sites 1-4; AI 1-4, Astola Island dive sites 1-4.

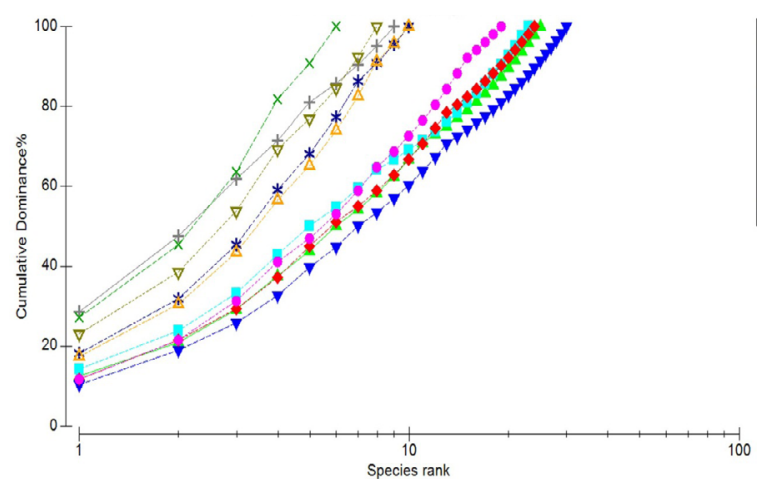

Fig. 3. K. dominance curve for fish communities at 10 dive sites. For abbreviations, see Figure 2. 
Table I. GPS positions, depths and general observations recorded at each dive site.

\begin{tabular}{lll}
\hline Dive sites & GPS positions & D \\
\hline Churna Islan 1 (CI 1) & $24^{\circ} 54^{\prime} .053^{\prime \prime} \mathrm{N}, 66^{\circ} 36^{\prime} .436^{\prime \prime} \mathrm{E}$ & 7 \\
Churna Island 2 (CI 2) & $24^{\circ} 53^{\prime} .982^{\prime \prime} \mathrm{N}, 66^{\circ} 36^{\prime} .464^{\prime \prime} \mathrm{E}$ & 7 \\
Churna Island 3 (CI 3) & $24^{\circ} 53^{\prime} .939^{\prime \prime} \mathrm{N}, 6^{\circ} 36^{\prime} .486^{\prime \prime} \mathrm{E}$ & 7 \\
Churna Island 4 (CI 4) & $24^{\circ} 53^{\prime} .878^{\prime \prime} \mathrm{N}, 66^{\circ} 36^{\prime} .547^{\prime \prime} \mathrm{E}$ & 7
\end{tabular}

Mubarak Village $1 \quad 24^{\circ} 51^{\prime} .625^{\prime \prime} \mathrm{N}, 66^{\circ} 39^{\prime} .780^{\prime \prime} \mathrm{E} \quad 2-5$ (MV1)

Mubarak Village $2 \quad 24^{\circ} 51^{\prime} .602^{\prime \prime} \mathrm{N}, 66^{\circ} 39^{\prime} .751^{\prime \prime} \mathrm{E} 3$ (MV2)

\begin{tabular}{lll} 
Astola Island (AI1) & $25^{\circ} 7^{\prime} .445^{\prime \prime} \mathrm{N}, 63^{\circ} 50^{\prime} .391$ & 3 \\
Astola Island (AI2) & $25^{\circ} 7^{\prime} .463^{\prime \prime} \mathrm{N}, 63^{\circ} 50^{\prime} .444 \mathrm{E}$ & 3 \\
& & \\
Astola Island (AI3) & $25^{\circ} 7^{\prime} .494^{\prime \prime} \mathrm{N}, 63^{\circ} 50^{\prime} .480$ & 3 \\
\hline Astola Island (AI 4) & $25^{\circ} 7^{\prime} .560^{\prime \prime} \mathrm{N}, 63^{\circ} 50^{\prime} .558^{\prime \prime}$ & 3
\end{tabular}

Physical parameters of seawater

No significant variations were recorded in seawater physical parameters. Maximum temperature was noted $27.07{ }^{\circ} \mathrm{C}( \pm 0.2+1)$ while minimum $26.05{ }^{\circ} \mathrm{C}$. High salinity value was $35.01 \%$ while minimum $34.10 \%$. High $\mathrm{pH}$ value was noted as $8.30( \pm 0.1)$ whereas minimum 8.0 $( \pm 0.1)$. High dissolved oxygen concentration was recorded as $6.36 \mathrm{mg} / \mathrm{L}( \pm 0.2+1)$. List of physical parameters recorded at each diving site are shown in Table III.

\section{Inorganic and organic contents of seawater}

High nitrate concentration was noted as 0.11 $\mu \mathrm{M} / \mathrm{L}$ while minimum $0.060 .11 \mu \mathrm{M} / \mathrm{L}$. High ammonia concentration was noted as $1.68 \mu \mathrm{M} / \mathrm{L}$ while minimum $1.16 \mu \mathrm{M} / \mathrm{L}$. Details about the concentrations of inorganic
The habitat at the 4 sites of CI was almost same. The substrate consisted of undulating rocks, boulders, mounds, gullies, fractures and ridges covered with thick algal turf. The corals were diverse with diverse growth forms (massive, encrusting, and submassive). The coral cover was approximately $55 \%$. High coral cover was at site 2 following 1, 3 and 4 . Fishes were abundant compare to any other site. The commonest species including Neopomacentrus sindensis, Neopomacentrus cyanomos, Neopomacentrus bankieri, Abudefduf vaigiensis and Sphyraena obtusata. Overall the community was dominated by damselfishes.

Located approximately 15 to $20 \mathrm{~m}$ offshore. The substrate consisted of uplifted rocks, ridges and occasional boulders on sandy bottom. Hard coral cover was approximately $20 \%$. The dominant genus was Porites with massive and encrusting growth forms. Coralline algae were dominant with approximately 60 $\%$ cover. Fishes were moderately abundant and the community was dominated by Neopomacentrus sindensis, Pristiapogon fraenatus, Pempheris malabarica and Pomacentrus caeruleus.

Located approximately $15 \mathrm{~m}$ offshore. The habitat was characterized by uneven but smooth rocks and boulders. Rocks were covered with algal turf. Coral cover was approximately 5\%. Fish diversity was low and the community was dominated by Neopomacentrus sindensis following Neopomacentrus bankieri and Abudefduf vaigiensis. Corals degradation at both sites of Mubarak Village was observed.

Rocky habitat with few uplifted boulders. Dominent corals were massive Porites species. Fish diversity was quite low

Rocky bed, with few sandy pockets and boulders. Low coral cover, consited of branching as well as massive and encrusting growth forms. Fish diversity was high compare to site 1 .

Similar habitat as in site 2. Fish diversity was quite well at this site.

Rocky habitat. Corals were consisted of massive Porites. Neopomacentrus sindensis was recorded as dominant.

and organic parameters noted at each diving sites are included in Table IV.

\section{DISCUSSION}

Habitats structured by corals with topographic complications (rocky outcrops) are to be considered as ideal places for fish accumulation. Several studies (Bell and Galzin, 1984; Sale and Douglas, 1984; Roberts and Ormond, 1987; Chabanet et al., 1997; Friedlander and Parrish, 1998; Ferreira et al., 2001; Almany, 2004; Sandin et al., 2008; Graham and Nash, 2013) have been undertaken in this regard. High fish diversity at CI might be due to the presence of complex habitat, structured by diverse forms of corals (e.g. encrusting, massive, 
Table II. Fish abundance and diversity documented at 10 dive sites. $6(D)=$ up to300 individuals; 5 (Abundant $)=$ up to 200 individuals; 4 (common) $=$ up to 50 individuals; 3 (frequent) $=$ up to 20 individuals; 2 (occasional) $=$ up to 10 individuals; 1 (rare) $=$ up to 5 individuals. CI 1-CI4: Churna Island dive sites 1-4; MV1-MV2: Mubarak Village dive sites 1-2; AI 1-AI 4: Astola Island dive sites 1-4.

\begin{tabular}{|c|c|c|c|c|c|c|c|c|c|c|c|c|}
\hline \multirow[t]{3}{*}{ Fish species } & \multirow[t]{3}{*}{ Family } & \multirow[t]{3}{*}{ Feeding level } & \multicolumn{6}{|c|}{ Sindh coast } & \multicolumn{4}{|c|}{ Balochistan coast } \\
\hline & & & \multicolumn{4}{|c|}{ Churna island } & \multicolumn{2}{|c|}{$\begin{array}{l}\text { Mubarak } \\
\text { village }\end{array}$} & \multicolumn{4}{|c|}{ Astola island } \\
\hline & & & CI 1 & CI 2 & CI 3 & CI 4 & MV1 & MV2 & AI 1 & AI 2 & AI 3 & AI 4 \\
\hline Abudefduf bengalensis & Pomacentridae & Planktivorous & 2 & 2 & 2 & 2 & 1 & & & & & \\
\hline Abudefduf sexfasciatus & Pomacentridae & Planktivorous & 1 & 1 & & & & & & & & \\
\hline Abudefduf vaigiensis & Pomacentridae & Planktivorous & 4 & 4 & 4 & 4 & 3 & 3 & 2 & 2 & 2 & 1 \\
\hline Amphiprion sandaracinos & Pomacentridae & Omnivorous & 1 & 1 & & & & & & & & \\
\hline Chromis flavaxilla & Pomacentridae & Planktivorous & 2 & & 1 & & & & & & & \\
\hline Chromis sp. & Pomacentridae & Planktivorous & 2 & & 2 & & & & & & & \\
\hline Neopomacentrus bankieri & Pomacentridae & Planktivorous & 4 & 4 & 4 & 4 & 3 & 4 & & & & \\
\hline Neopomacentrus cyanomos & Pomacentridae & Planktivorous & 4 & 4 & 4 & 4 & & & & & & \\
\hline Neopomacentrus sindensis & Pomacentridae & Planktivorous & 6 & 6 & 6 & 6 & 6 & 6 & 3 & 3 & 3 & 3 \\
\hline Neopomacentrus miryae & Pomacentridae & Planktivorous & 3 & 2 & 2 & 2 & & & & & & \\
\hline Pomacentrus caeruleus & Pomacentridae & Planktivorous & & & & 5 & 5 & & & & & \\
\hline Pristiapogon fraenatus & Apogonidae & Planktivorous & & & & & 5 & & & & & \\
\hline Archamia bleekeri & Apogonidae & Planktivorous & & 3 & 3 & & & & 2 & 3 & 3 & 2 \\
\hline Apogonichthyoides pseudotaeniatus & Apogonidae & Planktivorous & & 1 & & 1 & & & & & & \\
\hline Apogonichthyoides sialis & Apogonidae & Planktivorous & & & & 1 & & & & 1 & 1 & \\
\hline Ostorhinchus cookii & Apogonidae & Invertivorous & & & & 2 & & & & & & \\
\hline Ostorhinchus flagelliferus & Apogonidae & Invertivorous & & & & 2 & & & & & & \\
\hline Chlorurus bowersi & Scaridae & Herbivorous & & 2 & & 2 & 2 & 2 & & & & \\
\hline Chlorurus capistratoides & Scaridae & Herbivorous & & 2 & & 2 & 2 & & & & & \\
\hline Chlorurus sordidus & Scaridae & Herbivorous & & 2 & & & 2 & & & & & \\
\hline Scarus arabicus & Scaridae & Herbivorous & & & & 2 & 2 & & & & & \\
\hline Scarus zufar & Scaridae & Herbivorous & & 2 & & & 2 & & & & & \\
\hline Labroides dimidiatus & Labridae & Invertivorous & & & & & & 1 & & & & \\
\hline Halichoeres dussumieri & Labridae & Invertivorous & 1 & 1 & 1 & & & 1 & & & & \\
\hline Halichoeres nigrescens & Labridae & Invertivorous & & & & & & & 1 & 2 & 2 & 2 \\
\hline Halichoeres scapularis & Labridae & Invertivorous & 1 & 1 & & & & & & & & \\
\hline Pseudochromis aldabraensis & Pseudochromidae & Invertivorous & 1 & 1 & 1 & 1 & & & & 1 & & \\
\hline Pseudochromis nigrovittatus & Pseudochromidae & Invertivorous & 1 & & & & & & & & & \\
\hline Pseudochromis omanensis & Pseudochromidae & Invertivorous & & 1 & 1 & & & & & & & \\
\hline Pseudochromis springeri & Pseudochromidae & Invertivorous & 1 & 1 & 1 & 1 & 1 & & & & & \\
\hline Plectorhinchus gattuerinus & Haemulidae & Invertivorous & & & & 1 & & & & & & \\
\hline Plectorhinchus sordidus & Haemulidae & Invertivorous & & & & 1 & 1 & & & & & \\
\hline Pomadasys stridens & Haemulidae & Carnivorous & & & & 1 & & 1 & & & & \\
\hline Signanus javus & Siganidae & Herbivorous & & 1 & 1 & 1 & & & & & 2 & 1 \\
\hline Siganus luridus & Siganidae & Herbivorous & 1 & 1 & 1 & & & & & & & \\
\hline Signanus sp. & Siganidae & Herbivorous & 2 & & & & & & & & & \\
\hline Heniochus acuminatus & Chaetodontidae & Planktivorous & & & & & 2 & & & & & \\
\hline
\end{tabular}




\begin{tabular}{|c|c|c|c|c|c|c|c|c|c|c|c|c|}
\hline \multirow[t]{3}{*}{ Fish species } & \multirow[t]{3}{*}{ Family } & \multirow[t]{3}{*}{ Feeding level } & \multicolumn{6}{|c|}{ Sindh coast } & \multicolumn{4}{|c|}{ Balochistan coast } \\
\hline & & & \multicolumn{4}{|c|}{ Churna island } & \multicolumn{2}{|c|}{$\begin{array}{l}\text { Mubarak } \\
\text { village }\end{array}$} & \multicolumn{4}{|c|}{ Astola island } \\
\hline & & & CI 1 & CI 2 & CI 3 & CI 4 & MV1 & MV2 & AI 1 & AI 2 & AI 3 & AI 4 \\
\hline Heniochus diphreutes & Chaetodontidae & Planktivorous & & & & & 2 & & & & & \\
\hline Lutjanus lutjanus & Lutjanidae & $\begin{array}{l}\text { Invertevorous } \\
\& \text { Carnivorous }\end{array}$ & & 1 & & & & & & & & \\
\hline Lutjanus vitta & Lutjanidae & $\begin{array}{l}\text { Invertevorous } \\
\& \text { Carnivorous }\end{array}$ & & 1 & & 1 & & & 2 & 3 & 2 & 1 \\
\hline Epinephelus malabaricus & Serranidae & Carnivorous & & & 1 & & & & & & 1 & \\
\hline Epinephelus diacanthus & Serranidae & Carnivorous & & & & & & & & & 3 & 2 \\
\hline Acanthopagurs catenula & Sparidae & Invertivorous & 1 & & & & & & & & & \\
\hline Diplodus capensis & Sparidae & Invertivorous & 2 & & & & & 1 & 1 & 2 & & 1 \\
\hline Ctenochaetus striatus & Acanthuridae & Invertivorous & 1 & 1 & 1 & 1 & & & & & & \\
\hline Abalistes stellatus & Balistidae & Invertivorous & & & 1 & & & & & & & \\
\hline Sardenella sp. & Clupeidae & Planktivorous? & & & & 3 & 3 & & & & & \\
\hline Platax teira & Ephippidae & Omnivorous & 1 & 1 & & & & & & & & \\
\hline Karalla daura & Leiognathidae & Invertivorous & 3 & & & & 3 & 2 & & & & \\
\hline Scolopsis vosmeri & Nemipteridae & Invertivorous & & 1 & & 1 & 1 & & & 1 & & \\
\hline Pempheris malabarica & Pempheridae & Planktivorous & & 3 & & & 5 & & & & & \\
\hline Coeroichthys brachysoma & Scombridae & Carnivorous? & & 1 & 1 & & & & & & & \\
\hline Scorpaenopsis barbatus & Scorpaenidae & Carnivorous & & & 1 & & & & & & & \\
\hline Sphyraena obtusata & Sphyraenidae & Carnivorous & & 5 & & & & & & 4 & 4 & \\
\hline Pseudosynanceia sp. & Synanceiidae & Carnivorous & & & 1 & & & & & & & \\
\hline Lagocephalus sp. & Tetraodontidae & Carnivorous & 1 & 1 & 1 & & & & & & & \\
\hline Torpedo fuscomaculata & Torpedinidae & Carnivorous & 1 & & & & & & & & & \\
\hline Torpedo sinuspersici & Torpedinidae & Carnivorous & 1 & & 1 & & & & & & & \\
\hline Total species & & & 25 & 29 & 22 & 24 & 19 & 9 & 6 & 10 & 10 & 8 \\
\hline
\end{tabular}

Table III. Seawater physical parameters $(n=3) \pm S E$ recorded from coral habitats along the northern sheltered side of Astola Island (Balochistan), Pakistan. AI 1- AI4= Astola Island dive sites 1-4.

\begin{tabular}{lllllllll}
\hline Diving sites & \multicolumn{2}{l}{ Temperature $\left({ }^{\circ} \mathbf{C}\right)$} & \multicolumn{2}{l}{ Salinity (\%o) } & \multicolumn{2}{c}{ pH } & \multicolumn{3}{c}{ Dissolved oxygen (mg/L) } \\
\cline { 2 - 10 } & Mean & \pm SE & Mean & \pm SE & Mean & \pm SE & Mean & \pm SE \\
\hline AI 1 & 26.05 & 0.15 & 34.86 & 0.17 & 8.30 & 0.11 & 6.26 & 0.08 \\
AI 2 & 26.06 & 0.11 & 35.46 & 0.14 & 8.06 & 0.12 & 6.10 & 0.11 \\
AI 3 & 27.07 & 0.11 & 34.10 & 0.05 & 8.13 & 0.08 & 5.73 & 0.08 \\
AI 4 & 27.05 & 0.05 & 34.16 & 0.08 & 8.00 & 0.05 & 6.36 & 0.08 \\
\hline
\end{tabular}

submassive) and maximum coral cover that provided sheltered from predators and abundant food supply. Depth gradient could also be another factor for high diversity as high fish diversity was also reported from Arabian Gulf in offshore habitats at deeper depth (Coles and Tarr, 1990). Literature survey indicated the dominance of fishes in coral habitats with maximum branching growth forms and live coral cover (Sutton, 1985; Wilson et al., 2008). Further, the dominance of the damselfishes at CI compared to MV and AI also supported the relationship between coral cover and fish abundance as damselfishes are highly dependent on live coral cover (Sutton, 1985; Patton, 1994; Gratwicke and Speight, 2005; Wilson et al., 2008; Komyakova et al., 2013). Comparatively low fish diversity at MV might be due to 
Table IV. Average $(n=3)$ concentrations $M \pm S E$ of dissolved organic and inorganic nutrient noted from 4 dive sites at Astola Island along the Balochistan coast of Pakistan. Abbreviations are same as in Table III.

\begin{tabular}{|c|c|c|c|c|c|c|c|c|c|c|}
\hline \multirow[t]{2}{*}{ Diving sites } & \multicolumn{2}{|c|}{ Nitrate $(\mu \mathrm{M} / \mathrm{L})$} & \multicolumn{2}{|c|}{ Nitrite $(\mu \mathrm{M} / \mathbf{L})$} & \multicolumn{2}{|c|}{ Ammonia $(\mu \mathrm{M} / \mathrm{L})$} & \multicolumn{2}{|c|}{ Phosphate $(\mu \mathrm{M} / \mathrm{L})$} & \multicolumn{2}{|c|}{ Chlorophyll $(\mu \mathrm{g} / \mathrm{L})$} \\
\hline & Mean & $\pm \mathbf{S E}$ & Mean & $\pm \mathbf{S E}$ & Mean & $\pm \mathbf{S E}$ & Mean & $\pm \mathbf{S E}$ & Mean & $\pm \mathbf{S E}$ \\
\hline AI 1 & 0.11 & 0.00 & -0.07 & 0.00 & 1.68 & 0.32 & 0.24 & 0.01 & 0.00 & 0.00 \\
\hline AI 2 & 0.11 & 0.00 & -0.07 & 0.00 & 1.16 & 0.15 & 0.27 & 0.00 & 0.00 & 0.00 \\
\hline AI 3 & 0.11 & 0.00 & -0.08 & 0.00 & 1.28 & 0.30 & 0.32 & 0.06 & 0.00 & 0.00 \\
\hline AI 4 & 0.06 & 0.00 & 0.03 & 0.01 & 1.57 & 0.26 & 0.02 & 0.00 & 0.00 & 0.00 \\
\hline
\end{tabular}

less coral cover, lack of branching growth forms and excessive macroalgal growth. Macroalgae certainly decrease the growth rates of corals (McCook, 1999; Jompa and McCook, 2003; Box and Mumbay, 2007).

Poor fish diversity at AI was mainly due to the degradation of fish habitat (corals) especially branching and submassive forms (Pocillopora damicornis and Porites nodifera) on a large scale. The corals were uprooted either for sale or as ornaments. Other possible causes of habitat destruction observed were entangling of fishing nets, coral diseases, sediment load, deployment of lobster pots in shallow water and careless skin and scuba diving. Physical parameters especially temperature and high nutrient concentrations along with other factors such as decrease in coral grazing fishes and sediment load are major cause of reef degradation (Brown, 1997; Fitt et al., 2001; Szmant, 2002). But in this study, physiochemical parameters along the Balochistan coast (Astola Island) were found in limits as coral and fish prefer for their proper growth (Vine, 1986; Furnas, 1991; Precht and Aronson, 2004; Martin and Wuenschel, 2006; Munday et al., 2009; Trotter et al., 2011; Nowicki et al., 2012) compare to Sindh coast (Ali et al., 2017). According to Ali et al. (2014), Astola Island was a hot coral spot in offshore waters of Pakistan. Pocillopora damicornis and Porites nodifera were main reef builders at the Island with up to approximately $80 \%$ cover, but now are not prevalent and only few colonies were observed. Similarly, diverse fish communities were also observed. Appearance of different coral diseases could be the outcomes of habitat destruction. Emerging of coral diseases as a result of habitat destruction have been reported from Eilat coral reefs, Red Sea (Loya, 2007). Habitat destruction as a result of increasing human activities and diseases eliminated the fishes due to food shortage and lack of hiding spaces.

Large number of planktivorous (18 species) and invertivorous (16 species) fishes indicated that nutrient rich water start a food chain from phytoplankton to zooplankton to planktivorous that ultimately consumed by predators. Comparing coral associated fishes with reef fishes in the region i.e. 511 fish species from Oman (Fouda et al., 1998), 187 species from northern Arabian Gulf (Krupp and Miiller, 1994), 71 species from Bahrain (Smith et al., 1987), 101 species from Arabian Gulf (Coles and Tarr, 1990) and 43 species from Iranian off waters (Rezai and Savari, 2004) showed that reef associated fish diversity in coastal waters of Pakistan seemed to be much lower but comparable to Bahrain and better than Persian Gulf but in Persian Gulf environmental stressors and shallow depth also responsible for poor fish diversity (Coles, 1988; Randall, 1995). However, compare to volume of above mentioned studies, our study is conducted on a small scale. As the coast of Pakistan is quite large, it is expected that further studies will help in finding new coral habitats with maximum number of fishes and also to understand the relationships between coral and fish association in terms of physiological and environmental context.

\section{CONCLUSIONS}

As the coral associated fish communities of Pakistan are living in a threatened environment, the conservation efforts should focus on the establishment of MPAs (Marine Protected Areas) as better management of environment and ecosystems is possible through MPAs (Siddiqui et al., 2008). Although, Astola Island has already been declared as a marine protected area (Dawn, 2017) but MPA should not be confined to uplifted boundaries of the Island. According to Grimsditch and Salm (2006), there should be inclusion of all parameters necessary for the design of effective MPAi.e. have abilities to cope with environmental and anthropogenic changes and provide maximum habits for fish growth and by increasing microhabitats for fish communities through Low-tech coral rehabilitation and forming by the involvement of community (HernándezDelgado et al., 2018). Further, involvement of different stakeholders (well reputed research institutes, universities, dive centers, tour operators and local communities), making tourism laws and implantation on laws and to create awareness on the significance (ecological, commercial) of these precious natural resources in general public via print and electronic media for a sustainable ecotourism. Moreover, to better understand, monitoring and scientific 
research on different aspects is recommended.

\section{ACKNOWLEDGEMENTS}

The authors are thankful to the Director CEMB for providing research facilities.

Statement of conflict of interest

The authors have declared no conflict of interest.

\section{REFERENCES}

Ali, A., Siddiqui, P.J.A. and Aisha, K., 2017. Characterization of macroalgal communities in the coastal waters of Sindh (Pakistan), a region under the influence of reversal monsoons. Region. Stud. Mar. Sci., 14: 84-92. https://doi.org/10.1016/j. rsma.2017.05.008

Ali, A., Ormond, R., Leujak, W. and Siddiqui, P.J.A., 2014. Distribution, diversity and abundance of coral communities in the coastal waters of Pakistan. J. mar. biol. Assoc. UK., 94: 75-84. https://doi. org/10.1017/S0025315413001203

Ali, S.I.U. and Memon, G.M., 1995. Environmental geology of the Pakistan coast and its influence on corals, oysters, and mangroves. In: The Arabian sea living marine resources and the environment (eds. M.F. Thompson and N.M. Tirmizi). Lahore, Vanguard Books, pp. 575-585.

Almany, G.R., 2004. Differential effects of habitat complexity, predators and competitors on abundance of juvenile and adult coral reef fishes. Oecologia, 141: 105-113. https://doi.org/10.1007/ s00442-004-1617-0

Amir, S.A., Tanaka, F., Siddiqui, P.J.A. and Iwatsuki, Y., 2013. First records of two sparid species, Diplodus omanensis and Pagellus affinis (Perciformes: Sparidae) from western coast of Pakistan. Cybium, 37: 220-222.

Amir, S.A., Siddiqui, P.J.A. and Masroor, R., 2014. A new sparid fish of genus Sparidentex (Perciformes: Sparidae) from coastal waters of Pakistan (North Western Indian Ocean). Pakistan J. Zool., 46: 471477.

Amir, S.A., Siddiqui, P.J.A. and Masroor, R. 2016. Finfish diversity and seasonal abundance in the largest arid mangrove forest of the Indus Delta, Northern Arabian Sea. Mar. Biodiv. https://doi. org/10.1007/s12526-016-0613-Z

Bell, J.D. and Galzin, R., 1984. Influence of live coral cover on coral-reef fish communities. Mar. Ecol. Prog. Ser, 15: 265-274. https://doi.org/10.3354/ meps 015265

Bianchi, G., 1985. FAO species identification sheets for fishery purposes. Field guide to the commercial marine and brackish water species of Pakistan. Prepared with the support of PAK/77/033/ and FAO (FIRM) Regular Programme. FAO.

Box, S.J. and Mumby, P.J., 2007. Effect of macroalgal competition on growth and survival of juvenile Caribbean corals. Mar. Ecol. Prog. Ser, 342: 139149. https://doi.org/10.3354/meps342139

Bray, J.R. and Curtis, J.T., 1957. An ordination of the upland forest communities of southern Wisconsin. Ecol. Monogr., 27: 325-349. https://doi. org/10.2307/1942268

Brown, B.E., 1997. Coral bleaching: Causes and consequences. Coral Reefs, 16: S129-S138. https:// doi.org/10.1007/s003380050249

Bruno, J.F., Petes, L.E., Harvell, C.D. and Hettinger, A., 2003. Nutrient enrichment can increase the severity of coral diseases. Ecol. Lett., 6: 1056-1061. https:// doi.org/10.1046/j.1461-0248.2003.00544.x

Carpenter, K.E., Krupp, F., Jones, D.A. and Zajonz, U., 1997. FAO species identification guide for fishery purposes. The living marine resources of Kuwait, Eastern Saudi Arabia, Bahrain, Qatar, and the United Arab Emirates. Rome.

Chabanet, P., Ralambondrainy, H., Amanieu, M., Faure, G. and Galzin, R., 1997. Relationships between coral reef substrata and fish. Coral Reefs, 16: 93102. https://doi.org/10.1007/s003380050063

Chittaro, P., 2004. Fish-habitat associations across multiple spatial scales. Coral Reefs, 23: 235-244. https://doi.org/10.1007/s00338-004-0376-z

Clarke, K.R., 1993. Non-parametric multivariate analysis of changes in community structure. Austral. Ecol., 18: 117-143. https://doi. org/10.1111/j.1442-9993.1993.tb00438.x

Clarke, K.R. and Warwick, R.M., 2001. Changes in marine communities: an approach to statistical analysis and interpretation. PRIMER-E Plymouth.

Clarke, K.R. and Gorely, R.N., 2006. PRIMER v6: user manual tutorial. PRIMER-E, Plymouth.

Coles, S.L. and Tarr, A.B., 1990. Reef fish assemblages in the western Arabian Gulf: A geographically isolated population in an extreme environment. Bull. mar. Sci., 47: 696-720.

Coles, S.L., 1988. Limitations on reef coral development in the Arabian Gulf: temperature or algal competition. In: Proc. $6^{\text {th }}$ Int. Coral Reef Symp., 3: 211-216.

Couturier, C.S., Stecyk, J.A., Rummer, J.L., Munday, P.L. and Nilsson, G.E., 2013. Species-specific effects of near-future $\mathrm{CO} 2$ on the respiratory performance of two tropical prey fish and their predator. Comp. Biochem. Physiol. A Mol. Integr. 
Physiol., 166: 482-489. https://doi.org/10.1016/j. cbpa.2013.07.025

Dawn, 2017. Newspaper archives (Karachi), Pakistan, September 20, 2017.

Downing, N., 1985. Coral reef communities in an extreme environment: the northwestern Arabian Gulf. Proc. $5^{\text {th }}$ Int. Coral Reef Congr. Tahiti, 6: 343-348.

Enzor, L.A., Zippay, M.L. and Place, S.P., 2013. High latitude fish in a high $\mathrm{CO} 2$ world: synergistic effects of elevated temperature and carbon dioxide on the metabolic rates of Antarctic notothenioids. Comp. Biochem. Physiol. A Mol. Integr. Physiol., 164: 154161. https://doi.org/10.1016/j.cbpa.2012.07.016

Ferrari, M.C., McCormick, M.I., Munday, P.L., Meekan, M.G., Dixson, D.L., Lönnstedt, O. and Chivers, D.P., 2012. Effects of ocean acidification on visual risk assessment in coral reef fishes. Funct. Ecol., 26: 553-558. https://doi.org/10.1111/j.13652435.2011.01951.x

Ferreira, C.E.L., Goncalves, J.E.A. and Coutinho, R., 2001. Fish community structure and habitat complexity in a tropical rocky shore. Environ. Biol. Fish, 61: 353-369.

Fitt, W.K., Brown, B.E., Warner, M.E. and Dunne, R.P., 2001. Coral bleaching: interpretation of thermal tolerance limits and thermal thresholds in tropical corals. Coral Reefs, 20: 51-65. https://doi. org/10.1007/s003380100146

Fouda, M.M., Hermosa Jr, GV and Al-Harthi, S.M., 1998. Status of fish biodiversity in the Sultanate of Oman. Ital. J. Zool., 65: 521-525. https://doi. org/10.1080/11250009809386878

Friedlander, A.M. and Parrish, J.D., 1998. Habitat characteristics affecting fish assemblages on a Hawaiian coral reef. J. exp. Mar. Biol. Ecol., 224: 1-30. https://doi.org/10.1016/S00220981(97)00164-0

Froese, R. and Pauly, D., 2018. Fish base. World Wide Web electronic publication. www.fishbase.org.

Furans, M.J., 1991. Nutrient status and trends in waters of the Great Barrier Reef Marine Park, In: Land uses patterns and nutrient loading of the Great Barrier Reef region (ed D. Yellowless). James Cook University, Townsville, pp. 162-179.

Gladstone, W., Curley, B. and Shokri, M.R., 2013. Environmental impacts of tourism in the Gulf and the Red Sea. Mar. Pollut. Bull., 72: 375-388. https://doi.org/10.1016/j.marpolbul.2012.09.017

Graham, N.A.G. and Nash, K.L., 2013. The importance of structural complexity in coral reef ecosystems. Coral Reefs, 32: 315-326. https://doi.org/10.1007/ s00338-012-0984-y

Graham, N.A.J., Evans, R.D. and Russ, G.R., 2003. The effects of marine reserve protection on the trophic relationships of reef fishes on the Great Barrier Reef. Environ. Conserv., 30: 200-208. https://doi. org/10.1017/S0376892903000195

Gratwicke, B. and Speight, M.R., 2005. The relationship between fish species richness, abundance and habitat complexity in a range of shallow tropical marine habitats. J. Fish Biol., 66: 650-667. https:// doi.org/10.1111/j.0022-1112.2005.00629.x

Grimsditch, G.D. and Salm, R.V., 2006. Coral reef resilience and resistance to bleaching. IUCN, Gland, Switzerland. 52 pp.

Haq, B.U., 1988. Geological evolution of the Indian Ocean with special reference to the Arabian Sea. In: Marine science of the Arabian Sea (eds. M.F. Thompson and N.M. Tirmizi). Proc. Int. Conf. (March 1986). Washington, DC, Am. Inst. Biol. Sci., pp. 9-35.

Hay, M.E. and Rasher, D.B., 2010. Coral reefs in crisis: Reversing the biotic death spiral. Biol. Rep., 2: 71. https://doi.org/10.3410/B2-71

Hernández-Delgado, E.A., Mercado-Molina, A.E. and Suleimán-Ramos, S.E., 2018. Multi-disciplinary lessons learned from low-tech coral farming and reef rehabilitation: I. Best management practices. In: Corals in a changing World. In Tech. pp. 245268. https://doi.org/10.5772/intechopen.73151

Hernández-Delgado, E.A., Mercado-Molina, A.E., Alejandro-Camis, P.J., Candelas-Sánchez, F, Fonseca-Miranda, J.S., González-Ramos, C.M., Guzmán-Rodríguez, R., Mège, P., MontañezAcuña, A.A., Maldonado, I.O., Otaño-Cruz, A., Samuel, E. and Suleimán-Ramos, S.E., 2014. Community-based coral reef rehabilitation in a changing climate: lessons learned from hurricanes, extreme rainfall, and changing land use impacts. Open J. Ecol., 4: 918. https://doi. org/10.4236/oje.2014.414077

Heron, S.F., Maynard, J.A., Hooidonk, R.V. and Eakin, C.M., 2016. Warming trends and bleaching stress of the world's coral reefs 1985-2012. Sci. Rep., 6: 38402. https://doi.org/10.1038/srep38402

Hoda, S.M.S., 1988. Fishes from the coast of Pakistan. Biologia, 34: 1-37.

Jompa, J. and McCook, L.J., 2003. Coral-algal competition: macroalgae with different properties have different effects on corals. Mar. Ecol. Prog. Ser., 258: 87-95. https://doi.org/10.3354/ meps 258087

Kemp, J., 1998. Zoogeography of the coral reef fishes of the Socotra Archipelago. J. Biogeogr., 25: 919-933. 
https://doi.org/10.1046/j.1365-2699.1998.00249.x

Komyakova, V., Munday, P.L. and Jones, G.P., 2013. Relative importance of coral cover, habitat Complexity and diversity in determining the structure of reef fish communities. PLoS One, 8: $\quad$ e83178. https://doi.org/10.1371/journal. pone. 0083178

Krupp, F. and Miiller, T., 1994. The status of fish populations in the northern Arabian Gulf two years after the 1991 Gulf war oil spill. Cour. Forsch. Inst. Senckenberg, 166: 67-75.

Kuiter, R.H. and Debelius, H., 2007. World atlas of marine fishes. Ika Unterwasserarchiv, pp. 728.

Lambshead, P.J.D., Platt, H.M. and Shaw, K.M., 1983. The detection of differences among assemblages of marine benthic species based on an assessment of dominance and diversity. J. nat. Hist., 17: 859-874. https://doi.org/10.1080/00222938300770671

Loya, Y., 2007. How to influence environmental decision makers? The case of Eilat (Red Sea) coral reefs. J. Exp. mar. biol. Ecol., 344: 35-53. https:// doi.org/10.1016/j.jembe.2006.12.005

Maragos, J.E., Crosby, M.P. and McManus, J.W., 1996. Coral reefs and biodiversity: A critical and threatened relationship. Oceanography, 9: 83-99. https://doi.org/10.5670/oceanog.1996.31

Marshall, N.J., Jennings, K., McFarland, W.N., Loew, E.R. and Losey, G.S., 2003. Visual biology of Hawaiian coral reef fishes. III. Environmental light and an integrated approach to the ecology of reef fish vision. Copeia, 2003: 467-480. https://doi. org $/ 10.1643 / 01-056$

Martin, G.B. and Wuenschel, M.J., 2006. Effect of temperature and salinity on otolith element incorporation in juvenile gray snapper Lutjanus griseus. Mar. Ecol. Prog. Ser, 324: 229-239. https://doi.org/10.3354/meps324229

McCook, L.J., 1999. Macroalgae, nutrients and phase shifts on coral reefs: Scientific issues and management consequences for the Great Barrier Reef. Coral Reefs, pp. 357-367. https://doi. org/10.1007/s003380050213

Munday, P.L., Jones, G.P., Pratchett, M.S. and Williams, A.J., 2008. Climate change and the future for coral reef fishes. Fish Fish., 9: 261-285. https://doi. org/10.1111/j.1467-2979.2008.00281.x

Munday, P.L., Dixson, D.L., Donelson, J.M., Jones, G.P., Pratchett, M.S., Devitsina, G.V. and Døving, K.B., 2009. Ocean acidification impairs olfactory discrimination and homing ability of a marine fish. Proc. natl. Acad. Sci., 106: 1848-1852. https:// doi.org/10.1073/pnas.0809996106

Munday, P.L., McCormick, M.I. and Nilsson, G.E.,
2012. Impact of global warming and rising $\mathrm{CO} 2$ levels on coral reef fishes: What hope for the future? J. exp. Biol., 215: 3865-3873. https://doi. org $/ 10.1242 / \mathrm{jeb} .074765$

Naim, O., 1993. Seasonal responses of a fringing reef community to eutrophication (Reunion Island, Western Indian Ocean). Mar. Ecol. Prog. Ser., 99: 137-151. https://doi.org/10.3354/meps099137

Nilsson, G.E., Östlund-Nilsson, S. and Munday, P.L., 2010. Effects of elevated temperature on coral reef fishes: loss of hypoxia tolerance and inability to acclimate. Comp. Biochem. Physiol. A. Mol. Integr. Physiol., 156: 389-393. https://doi.org/10.1016/j. cbpa.2010.03.009

Nowicki, J.P., Miller, G.M. and Munday, P.L., 2012. Interactive effects of elevated temperature and $\mathrm{CO} 2$ on foraging behavior of juvenile coral reef fish. J. Exp. Mar. Biol. Ecol., 412: 46-51. https:// doi.org/10.1016/j.jembe.2011.10.020

Pastorok, R.A. and Bilyard, G.R., 1985. Effects of sewage pollution on coral-reef communities. Mar. Ecol. Prog. Ser., 21: 175-189. https://doi. org/10.3354/meps021175

Patton, W., 1994. Distribution and ecology of animals associated with branching corals (Acropora spp.) from the Great Barrier Reef, Australia. Bull. Mar. Sci., 55: 193-211.

Pet-Soede, C., Van Densen, W.L.T., Pet, J.S. and Machiels, M.A.M., 2001. Impact of Indonesian coral reef fisheries on fish community structure and the resultant catch composition. Fish Res., 51: 3551. https://doi.org/10.1016/S0165-7836(00)002368

Plaisance, L., Caley, M.J., Brainard, R.E. and Knowlton, N., 2011. The diversity of coral reefs: What are we missing? PLoS One, 6: e25026. https://doi. org/10.1371/journal.pone. 0025026

Pratchett, M.S., Hoey, A.S. and Wilson, S.K., 2014. Reef degradation and the loss of critical ecosystem goods and services provided by coral reef fishes. Curr. Opin. Environ. Sustain., 7: 37-43. https://doi. org/10.1016/j.cosust.2013.11.022

Precht, W.F. and Aronson, R.B., 2004. Climate flickers and range shifts of reef corals. Front. Ecol. Environ., 2: 307-314. https://doi.org/10.1890/15409295(2004)002[0307:CFARSO]2.0.CO;2

Randall, J.E., 1995. Coastal fishes of Oman. University of Hawaii Press, Honolulu, Hawaii, pp. 439.

Reese, E.S., 1975. A comparative field study of the social behavior and related ecology of reef fishes of the family Chaetodontidae. Ethology, 37: 3761. https://doi.org/10.1111/j.1439-0310.1975. tb01126.x 
Rezai, H. and Savari, A., 2004. Observation on reef fishes in the coastal waters off some Iranian Islands in the Persian Gulf. Zool. Middle East, 31: 67-76. https://doi.org/10.1080/09397140.2004.10638024

Riegl, B., 2002. Effects of the 1996 and 1998 positive sea-surface temperature anomalies on corals, coral diseases and fish in the Arabian Gulf (Dubai, UAE). Mar. Biol., 140: 29-40. https://doi. org/10.1007/s002270100676

Roberts, C.M. and Ormond, R.F.G., 1987. Habitat complexity and coral reef fish diversity and abundance on Red Sea fringing reefs. Mar. Ecol. Prog. Ser., 41: 1-8. https://doi.org/10.3354/ meps041001

Sale, P.F. and Douglas, W.A., 1984. Temporal variability in the community structure of fish on coral patch reefs and the relation of community structure to reef structure. Ecology, 65: 409-422. https://doi. org/10.2307/1941404

Sandin, S.A., Smith, J.E., DeMartini, E.E., Dinsdale, E.A., Donner, S.D., Alan, M., Friedlander, A.M., Konotchick, T., Malay, M., Maragos, J.E., Obura, D., Pantos, O., Paulay, G., Richie, M., Rohwer, F., Schroeder, R.E., Walsh, S., Jackson, J.B.C., Knowlton, N. and Sala, E., 2008. Baselines and degradation of coral reefs in the Northern Line Islands. PLoS One, 3: e1548. https://doi. org/10.1371/journal.pone.0001548

Shah, S.M.I., 2009. Stratigraphy of Pakistan. Government of Pakistan. Ministry of Petroleum and Natural Resources, Geological Survey of Pakistan. Memoirs of the geological survey of Pakistan 22.

Shameel, M. and Tanaka, J., 1992. A preliminary checklist of marine algae from the coast and inshore waters of Pakistan Cryptogamic Flora of Pakistan. Natl. Sci. Museum Tokyo, 1: 1-64.

Shulman, M.J., 1985. Recruitment of coral reef fishes: effects of distribution of predators and shelter. Ecology, 66: 1056-1066. https://doi. org/10.2307/1940565

Siddiqui, P.J.A., Farooq, S., Shafique, S. and Farooqi, Z., 2008. Conservation and management of biodiversity in Pakistan through the establishment of marine protected areas. Ocean. Coast. Manage., 51: 377-382. https://doi.org/10.1016/j. ocecoaman.2008.01.006

Smith, G., Saleh, M. and Sangoor, K.H., 1987. The reef ichthyo fauna of Bahrain (Arabian Gulf) with comments on its zoogeographic affinities. Arab. Gulf J. Sci. Res., 5: 127-146.

Strickland, J.D.H. and Parsons, T.R., 1972. A practical handbook of seawater analysis, Fisheries Research Board of Canada. second ed. Bulletin, pp. 167.

Sutton, M., 1985. Patterns of spacing in a coral reef fish in two habitats on the Great Barrier Reef. Anim. Behav., 33: 1322-1337. https://doi.org/10.1016/ S0003-3472(85)80194-9

Szmant, A.M., 2002. Nutrient enrichment on coral reefs: Is it a major cause of coral reef decline? Estuaries, 25: 743-766. https://doi. org/10.1007/BF02804903

Teh, L.C.L. and Sumaila, U.R., 2013. A global estimate of the number of coral reef fishers. PLOS ONE, 8: e65397. https://doi.org/10.1371/journal. pone. 0065397

Thompson, R. and Munro, J.L., 1978. Aspects of the biology and ecology of Caribbean reef fishes: Serranidae (hinds and groupers). J. Fish Biol., 12: 115-146. https://doi.org/10.1111/j.1095-8649.1978. tb04158.x

Trotter, J., Montagna, P., McCulloch, M., Silenzi, S., Reynaud, S., Mortimer, G., Martin, S., FerrierPagès, C., Gattuso, J.P. and Rodolfo-Metalpa, R., 2011. Quantifying the $\mathrm{pH}$ 'vital effect' in the temperate zooxanthellate coral Cladocora caespitosa: Validation of the boron seawater $\mathrm{pH}$ proxy. Earth Planet. Sci. Lett., 303: 163-173. https://doi.org/10.1016/j.eps1.2011.01.030

Veron, J.E.N., Devantier, L.M., Turak, E., Green, A.L., Kininmonth, S., Stafford-Smith, M. and Peterson, N., 2009. Delineating the Coral Triangle. Galaxea J. Coral Reef Stud., 11: 91-100. https://doi. org/10.3755/galaxea.11.91

Vine, P., 1986. Red Sea invertebrates. Immel Publishing, Ely House, 37 Dover Street, London.

Wiggert, J.D., Jones, B.H., Dickey, T.D., Brink, K.H., Weller, R.A., Marra, J. and Codispoti, L.A., 2000. The Northeast monsoon's impact on mixing, phytoplankton biomass and nutrient cycling the Arabian Sea. Deep-Sea Res. II, 47: 1353-1385. https://doi.org/10.1016/S0967-0645(99)00147-2

Williams, D.M. and Hatcher, A.I., 1983. Structure of fish communities on outer slopes of inshore, midshelf and outer shelf reefs of the Great Barrier Reef. Mar. Ecol. Prog. Ser., 10: 239-250. https:// doi.org/10.3354/meps010239

Wilson, S.K., Burgess, S.C., Cheal, A.J., Emslie, M., Fisher, R., Miller, I., polunin, N.V. and Sweatman, H.P., 2008. Habitat utilization by coral reef fish: implications for specialists vs. generalists in a changing environment. J. Anim. Ecol., 77: 220-228. https://doi.org/10.1111/j.1365-2656.2007.01341.x 